is being studied by the General Electric Co., Schenectady. The plant is to be housed in a hull of similar dimensions to that of a Great Lakes freighter capable of passing through the Welland Canal, the dimensions being limited to $290 \mathrm{ft}$. by $43 \mathrm{ft}$., with a draught of $10 \mathrm{ft}$. and a low-bridge clearance of $15 \mathrm{ft}$. It is recalled that this idea is not new, for two $10,000 \mathrm{kw}$. turbo-generators were installed in the hull of the Jacona, a vessel built during the War of 1914-18, and since 1930 used as a floating power plant in New England. This vessel was taken in hand at the works of the Newport News Shipbuilding and Dry Dock Co. The main engine boilers and auxiliary formerly used for propulsion were removed. The funnel, foremast and four forward winches, propeller, shaft-tunnel and shafting were removed. New watertight bulkheads were installed fore and aft, and special thickening was fitted underneath the power plant. Two steam turbo-generators were installed, taking steam from four marine boilers, delivering $280,000 \mathrm{lb}$. of steam per hour at $425 \mathrm{lb}$. pressure at $250^{\circ} \mathrm{F}$. superheat. The steam consumption of the turbines is about 9.4 lb. per $\mathrm{kwh}$. at full load, the turbines being directly connected. With the exception of a few auxiliaries, the whole of the plant is divisible into two separate units, two boilers being arranged to serve each turbine. The method of making electrical connexion to the shore is a problem involving considerable study.

\section{James Nasmyth as Tool Maker}

When James Nasmyth (1808-1890) was twentysix years of age he set up in business as an engineer in Manchester, and two years later, at Patricroft on the Bridgewater Canal, he established the famous Bridgewater Foundry, so named after the Great Duke. By 1856, Nasmyth was able to retire and devote himself to astronomy. The foundry, however, was carried on successfully by others until July 1940 . when it became a Government ordnance factory. One consequence of this was the presentation to the Institution of Mechanical Engineers, by Sir Holberry Mensforth, of Nasmyth's well-known "Sketch Book" and a portfolio of early drawings. Most of the drawings are of steam hammers, but others relate to machine tools. Some of these are of exceptional interest, and in The Engineer of May 23, Dr. H. W. Dickinson gives a review of Nasmyth's pioneering work in this department of engineering. As an appendix to the article a transcription is given of a letter written in 1864, in which Nasmyth refers to his discovery of the 'willow leaf' pattern on the sun's surface, a discovery which "has made a great stir among astronomers".

\section{Activated Charcoals from Peat Residue}

IN the tenth part of a series of "Studies in Peat", J. Reilly and J. R. O'Donoghue (Sci. Proc. Roy. Dublin Sor., 22 (N.S.), 367 ; 1941) report experiments on the preparation of activated charcoals from peat. Before preparing the charcoal, waxy constituents were removed. Of various methods used, activation with superheated steam, and, to a lesser extent, by treatment with syrupy phosphoric acid before carbonization were found to be best for producing charcoals of performance approaching commercial standards. So far as is known, the peat residue is the first substance of Irish origin to be examined as a source of active charcoal.

\section{Earthquakes in Turkey}

That the earth's crust has not yet settled down after the disastrous Turkish earthquakes of December 1939 is evidenced by recent earthquake activity in that country. Minor shocks are frequently experienced, and stronger ones occur from time to time. Two such happened during the last fortnight. A strong earthquake on May 24 broke the sea wall at Mugla, opposite the island of Rhodes. Some other damage and twenty casualties have been reported at Mugla, and less intense shocks were experienced at Smyrna. During the night of May 30-31, a strong tremor was felt in Anatolia, causing serious damage to a large number of houses. No casualties have been reported as a result of this shock.

\section{Announcements}

Prof. L. J. Mordel, F.R.S., Fielden professor of pure mathematies in the University of Manchester, has been awarded the De Morgan Medal of the London Mathematical Society.

DR. J. A. VENN, president of Queens' College, Cambridge, and Gilbey lecturer in agricultural economics and history, has been elected vice-chancellor of the University for the academical year beginning on October 1, in succession to Mr. E. A. Benians, master of St. John's College, who has held the office for the customary two years.

The Adams Prize for 1939-40, valued at about $£ 268$, has been awarded to Dr. Harold Davenport, assistant lecturer in mathematics in the University of Manchester. Dr. Davenport, who graduated as a wrangler, was formerly a fellow of Trinity College.

The herbarium near Hudiksvall, in Sweden, containing thirty thousand specimens of roses, compiled and classified by the late Reinhold Matsson, the Swedish botanist, has been destroyed by a fire.

A NEW division of chemotherapy has been formed in the National Institute of Health of the United States Public Health Service to be under the direction of Dr. William H. Sebrell, jun. The new unit will be concerned with research on sulphanilamide products and with new synthetic drugs with antimalarial properties, in order to make the United States independent of the Dutch East Indies supply of quinine. The division will have quarters at the National Institute of Health in Bethesda, Maryland. The building will also be the headquarters of the divisions of chemistry and zoology.

Erratum. The title of the letter by Dr. H. L. A. Tarr in Nature of April 5, p. 417, should read "The Bacteriostatic Action of Nitrites"; thus the work relates to "nitrites" and not to "nitrates" as printed. 